\title{
Evaluation of Board Game about Immunopreventable Diseases for Higher Education in Health Course
}

\author{
Clara Fernanda Gonçalves de Carvalho, Rafaela Feitosa Coutinho, \\ Isabela Dantas de Araujo Lima, Casandra G. R. M. Ponce de Leon, Laiane Medeiros Ribeiro, \\ Géssica Borges Vieira, Laise Escaliante Del Alamo Guarda, Rayanne Augusta Parente Paula, \\ Sammya Rodrigues dos Santos
}

Department of Nursing, Faculty of Ceilândia, University of Brasília, Brasília, Brazil

Email: casandrapleon@gmail.com

How to cite this paper: de Carvalho, C. F. G., Coutinho, R. F., de Araujo Lima, I. D., de Leon, C. G. R. M. P., Ribeiro, L. M., Vieira, G. B., Del Alamo Guarda, L. E., Paula, R. A. P., \& dos Santos, S. R. (2018). Evaluation of Board Game about Immunopreventable Diseases for Higher Education in Health Course. Creative Education, 9, 646-657.

https://doi.org/10.4236/ce.2018.95047

Received: January 10, 2018

Accepted: April 16, 2018

Published: April 19, 2018

Copyright ( $) 2018$ by authors and Scientific Research Publishing Inc. This work is licensed under the Creative Commons Attribution International License (CC BY 4.0).

http://creativecommons.org/licenses/by/4.0/

\section{(c) (†) Open Access}

\begin{abstract}
Objective: To evaluate an educational technology like a board game titled "ImmunizAction", with undergraduate students. Methodology: Methodological study, the board game evaluation was collected in a public University of Brasília, in October 2016. Participated 26 students of nursing and pharmacy courses. Evaluated through the adapted instrument of educational games proposed by Savi, Wangenheim, Ulbricht, Vanzin. Results: The questionnaire had 27 questions, and evaluated the motivation, user experience and knowledge. Within Motivation, attention, relevance, trust and satisfaction were observed. In the Game User Experience, immersion, challenge, social interaction and fun were evaluated. The analysis of the data reveals approval of more than $70 \%$ in the items of the instrument of evaluation in a Likert scale in almost all the components. Conclusion: Educational game board technologies can be used as a facilitator in knowledge construction.
\end{abstract}

\section{Keywords}

Higher Education, Immunization, Educational Technology, Nursing Education

\section{Introduction}

It is possible to observe the increasing number of educational technologies use in universities and institutions of higher education, bringing innovation and creativity to the practices of education, necessary in the education due to the stu- 
dents' profile. Technologies that serve as a tool in the teaching and learning process highlight it as an alternative method in this process.

Nowadays, the profiles of the students consist of young people belonging to several generations, grown in a technological age (Sangiorgio, Gabriel, Moreira, \& Tanaka, 2011) stands out the $\mathrm{Y}$ and $\mathrm{Z}$ generations. Those born in generation $\mathrm{Y}$ represent those who constantly live with the "information update", the Internet Generation (Sangiorgio, Gabriel, Moreira, \& Tanaka, 2011). Born between 1980 and 1990 they have an advanced intellectual level due to the range of information they receive, and the internet has their largest means of information. Generation $\mathrm{Z}$ includes individuals who were born after the early 1990s, before the internet and technology (Santos \& Lisboa, 2014).

Generation $\mathrm{Z}$ presents some characteristics (Toledo, Albuquerque, \& Magalhães, 2012) as people who "[...] perform various tasks at the same time, are immediate, critical, change their minds several times. Concerned about environmental issues, they will be more demanding, versatile and flexible professionals."

This generation of young students does not fit traditional tasks, born in the era of technologies, computers and internet, are accustomed to the agility and dynamicity of information, hence the need for teachers to innovate, adding new methods and creating teaching strategies where the student can learn and, at the same time, interact with other peers (Sangiorgio, Gabriel, Moreira, \& Tanaka, 2011).

In this perspective, the use of games refers to a critique to the traditional teaching method, where the educator comes as the main mediator between the student and the knowledge, the university professor "has the role of facilitator, guiding and encouraging in the teaching-learning process of the student (Medeiros, Lima, Silva, \& Mercado, 2015).

The games provide a better interaction between student, teacher and knowledge. To develop content delivered in class, educational games are used as stimulants of creativity and facilitators in the teaching-learning process (Gurgel \& Fernandes, 2015).

In nursing, educational games are used as a teaching tool, because within their approach one can develop the practical theoretical content thus distancing itself from the traditional model that is transmitted in the classroom. A study concluded that board games serve as a teaching-learning strategy, as it encourages the learner's interest in the subject and also allows the acquisition of new knowledge and skills, also serves to review contents and increase the attention of the learner (Fernandes, 2016).

In nursing, the use of ludic has been used as a tool for interaction and transmission of knowledge, providing for those who play a better understanding of the environment that it is inserted, also for the student the construction of their own "autonomous, able to think for themselves" profile (Rufino, 2014).

In Brazil there are already several games directed to health education with re- 
levant themes on diabetes, infant respiratory infections, puerperium care, drugs, AIDS, STDs among others (Perim, Giannella, \& Struchiner, 2014). In the College of Ceilândia-University of Brasília-Brazil, the discipline Comprehensive Care for Women and Children's Health, addresses in its programmatic content the prevention of diseases through immunization. However, this content is extensive and requires more time to be taught, so the game entitled "ImmunizAction" provides a didactic and educational learning and reinforcement of the theme on immunopreventable diseases. So, the main question of this study is: does this board game with contents related to immunopreventable diseases contribute didactically to the learning of nursing students?

In view of the above, and with an educational game developed in the discipline we sought to evaluate how the educational technology: "ImmunizAction" interferes with the participant, whether in the part of the emotions, in the reaction, in the interaction, in the acquisition of new knowledge that can come from an interaction with some educational technology.

\section{Methodology}

This is a methodological study for evaluation of a board educational game, carried out with a convenience sample of 26 students, from the nursing and pharmacy course of the Ceilândia campus of the University of Brasília, in the period of October 2016. The inclusion criteria were to be a graduate student of the health courses. As exclusion criterion, be absence from the University on the day of data collection. This occurred after the participation of the academics in the workshop held at the University Extension Week of the University of Brasília on "The Ludic in Higher education", where the students were invited by one of the authors, from whom they received all the information about the objectives of the research.

As a theoretical reference for the evaluation of the game in the student learning process, we use Kirkpratick level 1 (on the subject's reaction to an activity) along with the ARCS (motivation to learn) model. ARCS is an acronym that identifies four categories of strategies that are important to motivate learners to learn: Attention, Relevance, Confidence, and Satisfaction (Keller, 2009).

The user experience was evaluated (User eXperience-UX), which focuses on the perception and response of a person about the use of a product, system or service (Takatalo, Hakkinen, Kaistinen, \& Nyman, 2010). And finally, the Bloom Taxonomy that describes the cognitive levels that students are expected to learn: 1) knowledge (remember); 2) understanding (understanding); 3) application (apply); 4) Analysis (analyze); 5) Evaluation (evaluate) and 6) Synthesis (create) (Ferraz \& Belhot, 2010).

The "ImmunizAction" game (Figure 1) was built to be applied on a board with nurse-pawns (first made out of EVA (Ethylene Vinyl Acetate) but then out of cold porcelain (Figure 2), due to its higher strength and durability), cards (so-called "questions" and "luck or setback") (Figure 3) and two dice for players 
to move across the board which contains illustrative images of "syringe", "medicine", "stethoscope" and "heart". Falling in the syringes house, students should respond to the "questions" card and in the other images they should respond to the card "luck or setback". The figures below of the board game follows next.

The questionnaire used for the evaluation of the board game was adapted from the instrument of Savi, Wangenheim, Ulbricht and Vanzin (Savi, Wangenheim, Ulbricht, \& Vanzin, 2010), with author's consent, on a Likert scale,
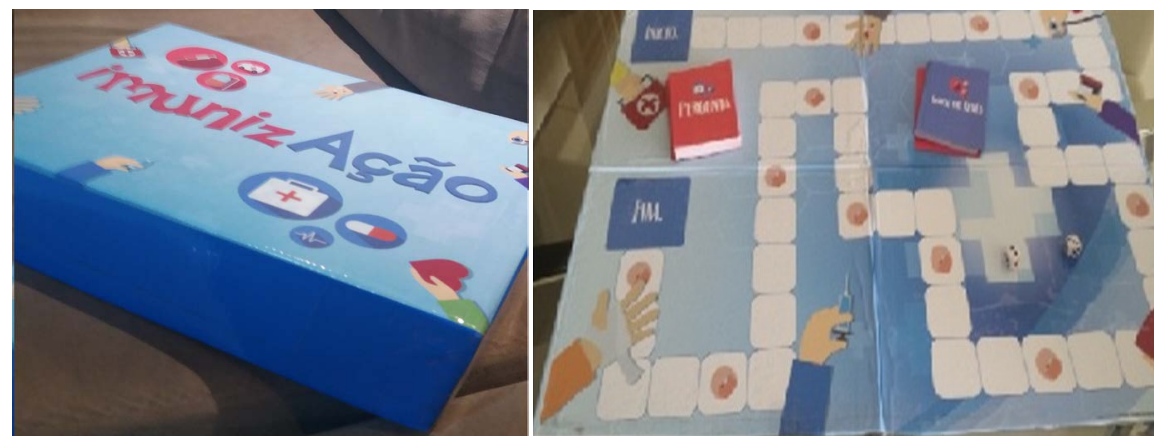

Figure 1. Box game and the board game.

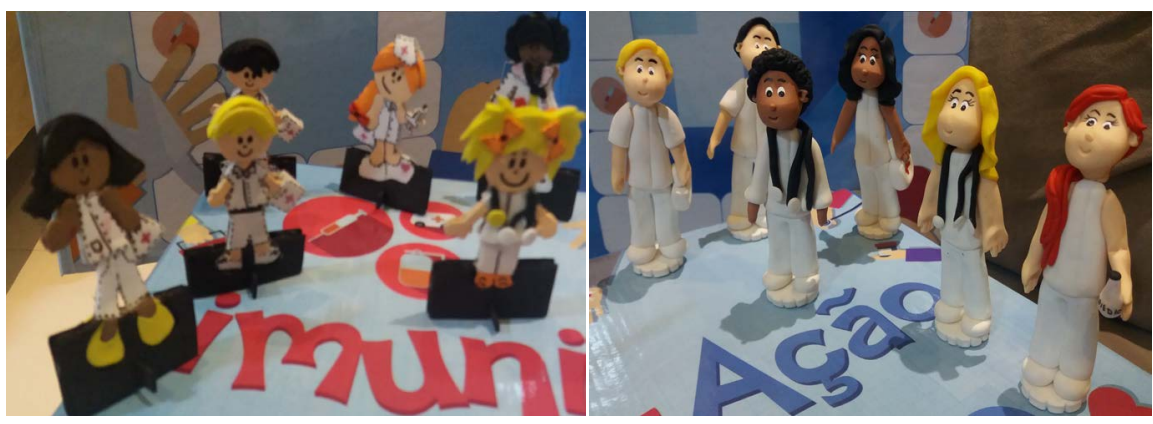

Figure 2. First pawns of EVA (Ethylene Vinyl Acetate), then made with cold porcelain.
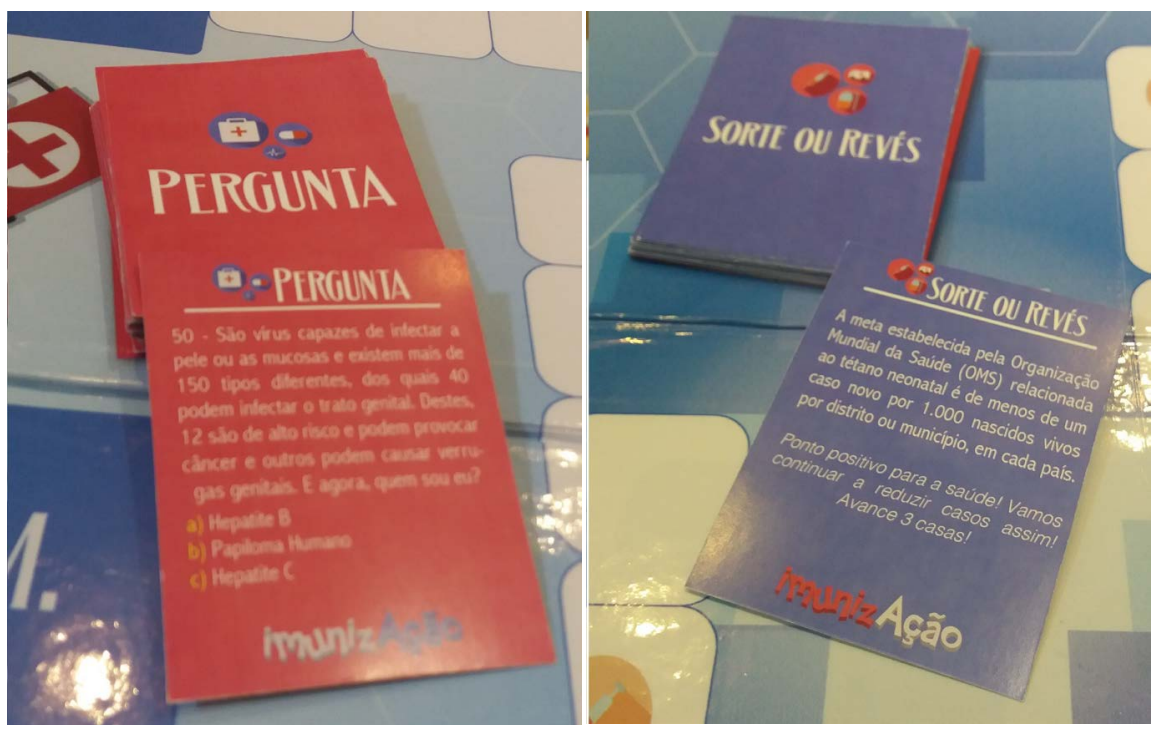

Figure 3. "Question" card and "luck or setback" cards. 
from 1 to 5, being 1 -totally disagree; 2-moderately disagree; 3-indifferent; 4-agree moderately; 5-totally agree (see Appendix).

The evaluation instrument applied to the students contained 27 questions to answer about the board game. The chosen axes were motivation, user experience and knowledge acquisition.

The theoretical model used for the evaluation of educational games was a mix of models, such as the ARCS model that evaluates the level of motivation of the students when using the game, which involves attention, relevance, reliability, satisfaction. The user experience area (User eXperience-UX) that evaluates the level of fun. Finally, Bloom's Revised Taxonomy Learning Model evaluates knowledge (remember, understand and apply) (Savi, Wangenheim, Ulbricht, \& Vanzin, 2010).

To answer the questionnaire, all participants were invited to practice the board game in a classroom designed for this activity. Initially, the rules of the game were exposed and it was given a time of 20 to 30 minutes to experience the board game. After playing, all participants were, again, invited to answer the evaluation questionnaire. They were free to accept or decline this invitation. The evaluation had an average duration of 18 minutes per participant.

From the data collected, a spreadsheet database was created in Microsoft Excel for coding variables (motivation, user experience and knowledge acquisition). These were typed twice to ensure the reliability of the data. Subsequently a simple analysis of the data with descriptive statistics was concretized.

\section{Ethical Approval}

This research was approved by the Research Ethics Committee of the Faculty of Health Sciences of the University of Brasília under the number CAAE: 30445614.2.0000.0030 of the National Commission for Research Ethics (CONEP), which is directly linked to the National Health Council (CNS) of the Ministry of Health. All international and national ethical principles were fulfilled in the accomplishment of this study.

\section{Findings}

Twenty-six students participated in the study, of which 22 were from the nursing course and 4 from the pharmacy course. The mean age of participants was 21 years, and the majority were female (92.3\%).

The questionnaire assessed the motivation with a total of 13 questions, and its subgroups: attention $(n=2)$, relevance $(n=5)$, reliability $(n=4)$, satisfaction $(n$ $=2)$. Game User Experience presented 11 items: immersion $(n=4)$, challenge ( $n$ $=3)$, social interaction $(n=2)$, fun $(n=2)$. And the Knowledge Axis with $(n=3)$ questions.

The evaluation performed according to the Likert scale of 5 points, about Motivation (Table 1 ).

In the data collection instrument were added columns 1 and 2 and highlighted 
as "DISAGREE", as well as answers 4 and 5 were added and highlighted in column "AGREE". The responses scored on the Likert scale as 3 were disregarded for the analysis in the study because they referred to a small value (of participants indifferent to the item evaluated).

The questions on Motivation (Table 1) were grouped into four blocks: attention, relevance, reliability and satisfaction. Regarding the interface of the game something attracted the attention of $92.3 \%$ ( 24 participants), with respect to questions related to the opinion about the relevance of the game to the learning 90.7\% (average of 23.6 participants) agreed with the questions.

The questions that compose the part of the reliability in the content of the game and in the knowledge that they had revealed $82.7 \%$ (average of 21.5 participants) of answers disagreeing that the game did not offer reliability to the players. $75 \%$ (average of 19.5 participants) replied that they felt satisfaction in completing the game.

The User Experience (Table 2) with the board game involves questions about the participant's immersion while playing, and got $67.3 \%$ match (average of 17.5 participants) with the items. Regarding the feeling generated by the participants

Table 1. Evaluation of the motivation that emerged in the students after experiencing the board game "ImmunizAction". ( $\mathrm{N}=$ 26).

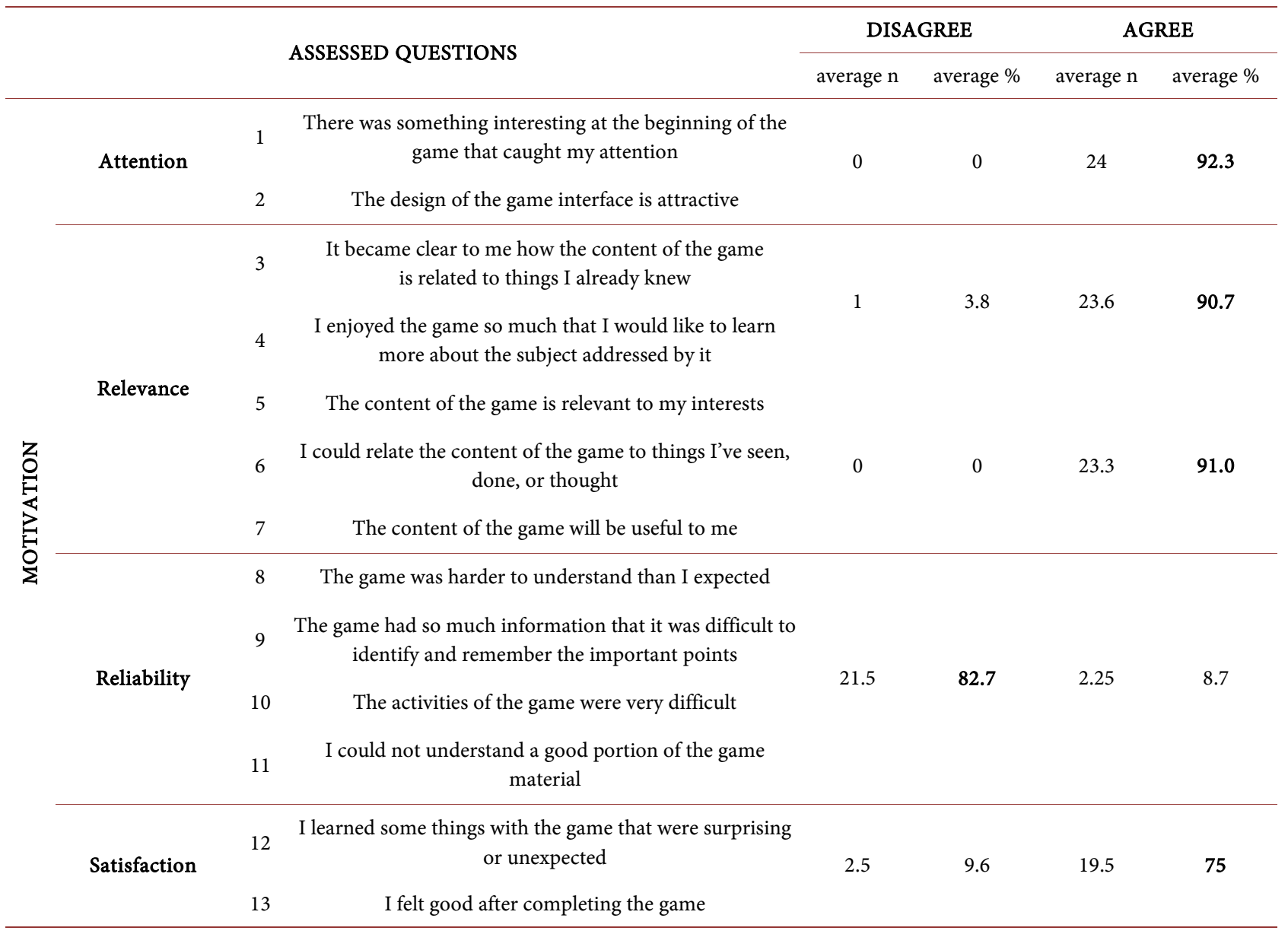


Table 2. Result of the evaluation of the students' experience when playing the educational board game "Immuniz Action" (N = 26).

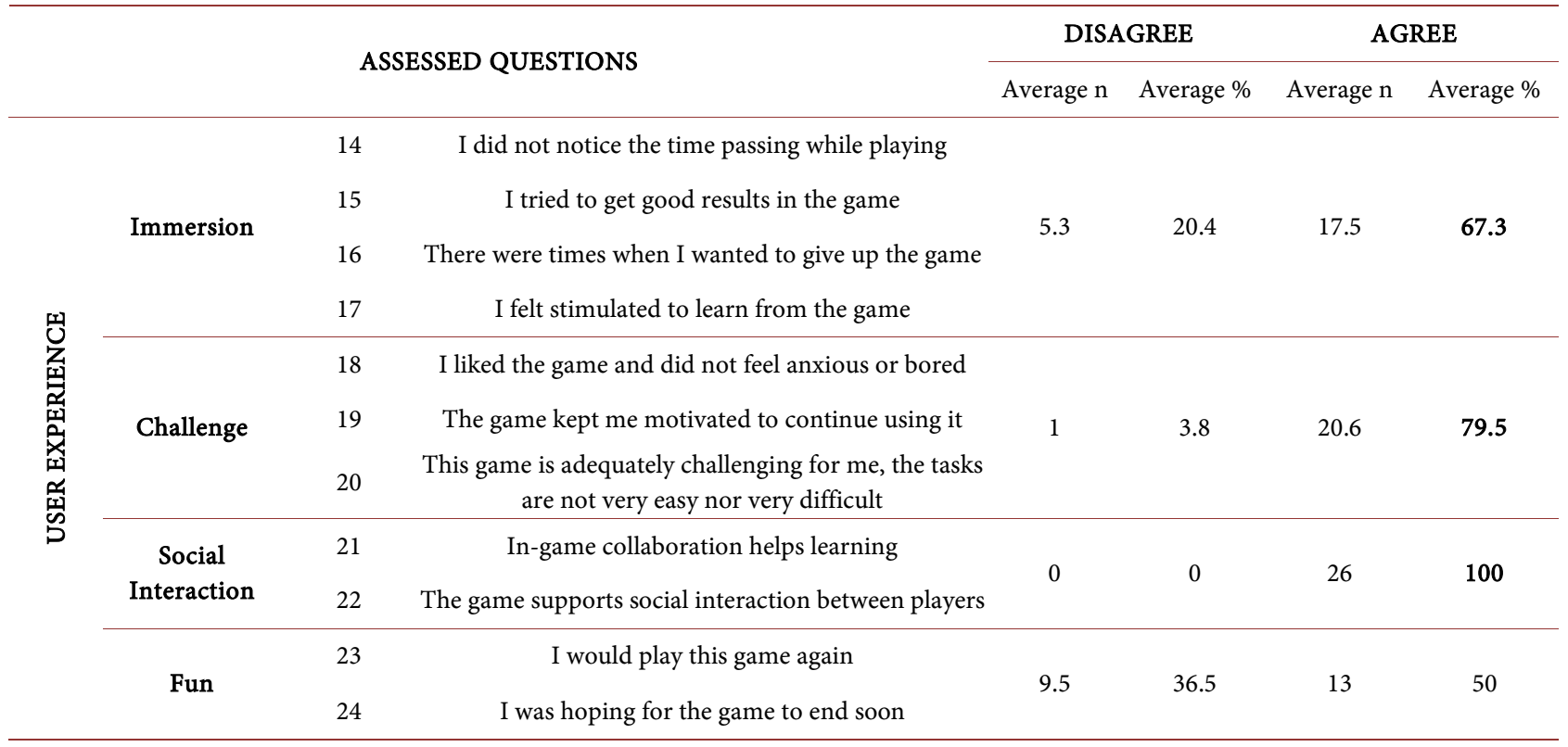

about the challenge that the game caused in them, $79.5 \%$ (average of 20.6 participants) responded that they agreed with the level of provocation of the game, which was neither easy nor too difficult.

Social interaction questions were $100 \%$ (26 participants) of agreement and the questions about fun obtained 50\% agreement (average of 13 participants).

In the evaluation of the perception about the Knowledge acquired by the game (Table 3) the students agree with $82.1 \%$ that the game they could remember more information about the content of the game.

\section{Discussion}

The use of educational games in the higher education environment is still not a regular activity, with little adherence in academia, often because of the cost of creating and validating a game, but also because some teachers do not consider that there is a real learning through educational games.

You can find some educational strategies such as: educational games, educational games and digital games. Ferri and Soares mention that games are "attractive, motivating and dynamic", thus favoring the environment in the student to arouse the desire to learn (Ferri \& Soares, 2015).

The university professor plays an important role in the process of teaching and learning acting as a facilitator and, in addition, motivator of the learning. Educational games propose this dynamic that promote innovative interaction among students, therefore, "teachers use games as a teaching strategy, making learners capture knowledge" (Medeiros, Lima, Silva, \& Mercado, 2015).

In this view the game enters as the main motivator, because its ability to entertain and draw the attention of the student is intrinsic. During the development 
Table 3. Students' perception of the knowledge acquired by the game. $(\mathrm{N}=26)$.

\begin{tabular}{|c|c|c|c|c|c|c|}
\hline & & \multirow{2}{*}{ ASSESSED QUESTIONS } & \multicolumn{2}{|c|}{ DISAGREE } & \multicolumn{2}{|c|}{ AGREE } \\
\hline & & & Average $n$ & Average \% & Average $n$ & Average \% \\
\hline \multirow{3}{*}{ KNOWLEDGE } & 25 & $\begin{array}{l}\text { After the game I can remember more information } \\
\text { related to the theme presented in the game }\end{array}$ & \multirow{3}{*}{0} & \multirow{3}{*}{0} & \multirow{3}{*}{21.3} & \multirow{3}{*}{82.1} \\
\hline & 26 & $\begin{array}{l}\text { After the game I can better understand the themes } \\
\text { presented in the game }\end{array}$ & & & & \\
\hline & 27 & $\begin{array}{l}\text { After the game I feel that I can better apply } \\
\text { the themes related to the game }\end{array}$ & & & & \\
\hline
\end{tabular}

of a classroom activity, it transforms "dull" content into an innovative and creative class (Silva \& Morais, 2011).

The theme covered in the board game "ImmunizAction" was as immunopreventable diseases, content that has been taught in the classroom by nursing course teachers. Immunization and prevention of child health problems are extremely important issues for the population, as it helps reduce mortality, as well as immunopreventable diseases. With this, Brazil has been able to eliminate poliomyelitis by interrupting the transmission of measles and rubeola, reducing the incidence of diphtheria among other diseases (Braz, Domingues, Teixeira, \& Luna, 2016).

The future nurse needs to have the skills and competencies to act before the Immunization scenario, and to achieve this, will make use of the memory regarding the information that is inherent to this practice.

The use of educational games in the health area is not something new, there are games that permeate various topics such as STDs, AIDS, Drugs, Immunization, Patient Safety, among others. This approach makes us think that the use of games provides a reflection on traditional pedagogical models, bringing a new perspective on health education (Yonekura \& Soares, 2010). The ludic, then, has been introduced as an additional knowledge tool (Dias, Mekaro, Lu Cheng, Sorrentino, Santiago, Otsuka, Beder, Bordini, \& Zem-Mascarenhas, 2014).

Recently a board game was developed in Portugal entitled Family Nursing Game, with the objective of "describing the development of a didactic material" which deals with questions about family and hospitalized family nursing. Bringing a reflection on the importance of the game, in its way of promoting interaction and reflection to the participants on the subject addressed (Fernandes, 2016).

The board game, besides being used as an instrument of educational evaluation, facilitates the construction of knowledge (Mariano, Pinheiro, Aquino, Ximenes, \& Pagliuca, 2013). Educational and playful games provide "a questioning cognitive process", favoring critical thinking in the absorption of knowledge.

The use of ludic in Higher Education is considered by researchers as important because through this strategy it is possible to perceive "how is the content and the assimilation of it" (Silva \& Rosa, 2010). There are two board games for the Recriate Project, developed at the University of Brasília entitled BANFISA and (IN) DICA-SUS, which deal with concepts about SUS (Unified Health Sys- 
tem) management, organization and functioning, and aims to analyze learning during the games (Silva \& Rosa, 2010).

Given the use of games in an educational environment, the ludic is highlighted with an educational activity that provides a relaxed atmosphere. It can be related to the age and generation of the participants, who are more familiar with the media technologies. Thus, despite this result, it is considered that the game was well evaluated for use in higher education.

As a limitation of the study, we have the methodology chosen, that didn't applied a pre test and post test to evaluate the gain of information using this game, and future studies could verify if the board game is, in fact usefull for a knowledge increasing in health students. More studies with different methodologies are recommended to contribute to the knowledge of the use of educational board games in higher education.

With the present study it was possible to realize that a board game that addresses the theme in question was well accepted as an educational tool in higher education.

\section{Summary}

Given the observed aspects, the use of games as a learning strategy can be used in the classroom through the application of extensive contents such as preventable immunity diseases, its use acts as a facilitator in the construction of knowledge. Generations within universities require the use of innovative technologies, and the teacher as a mediator of education should seek to be aware of such technologies.

Although they are little used, board games arouse curiosity of those who play, promote interaction among the participants, and this is a positive aspect for their use. The studies that were presented explore the game as an educational tool that brings improvements to the education of health professionals, while promoting didactic contents listed in the training.

In view of the above, the challenge is to teach using educational technologies in order to overcome traditional teaching approaches, either in undergraduate courses or with professionals who seek to update knowledge. We understand that educational games can be used as an educational tool, either as part of the evaluation process or as part of the teaching process, contributing to the training and qualification of nurses.

\section{References}

Braz, R. M., Domingues, C. M., Teixeira, A. M., \& Luna, E. J. A. (2016). Classificação de risco de transmissão de doenças imunopreveníveis a partir de indicadores de coberturas vacinais nos municípios brasileiros. Epidemiologia e serviços de saúde, 25, 1 .

Dias, J. D., Mekaro, M. S., Lu Cheng, J. K., Sorrentino, G. S., Santiago, D. L., Otsuka, J. L., Beder, D. M., Bordini, R. A., \& Zem-Mascarenhas, S. H. (2014). DIGESTOWER: Jogo educacional para auxiliar o enfrentamento da obesidade infantil. In XIX Conferência 
Internacional sobre Informática na Educação (pp. 309-317). Fortaleza: Instituto UFC Virtual TISE, Universidade Federal do Ceará (UFC).

http://www.tise.cl/volumen10/TISE2014/tise2014_submission_297.pdf

Fernandes, C. S. (2016). Family Nursing Game: Desenvolvendo um jogo de tabuleiro sobre Família. Esc Anna Nery, 20, 33-37. http://dx.doi.org/10.5935/1414-8145.20160005

Ferraz, A. P., \& Belhot, R. V. (2010). Taxonomia de Bloom: Revisão teórica e apresentação das adequações do instrumento para definição de objetos instrucionais. Gestão e Produção, 17, 421-431. https://doi.org/10.1590/S0104-530X2010000200015

Ferri, K. C., \& Soares, L. M. (2015). O Jogo de Tabuleiro como Recurso Didático no Ensino Médio: Uma Contextualização do Ensino de Química (pp. 315-327). XII Semana de Licenciatura III Seminário de Pós-Graduação em Educação para Ciências e Matemática I Encontro de Egressos do Mestrado, Jataí.

Gurgel, P. C., \& Fernandes, M. C. (2015). Jogos Educacionais no Ensino da Enfermagem em Saúde coletiva: Relato de Experiência. Rev enferm UFPE, 9, 9320-9323.

Keller, J. M. (2009). Motivational Design for Learning and Performance: The ARCS Model Approach. Florida: Springer.

Mariano, M. R., Pinheiro, A. K., Aquino, P., Ximenes, L. B., \& Pagliuca, L. M. F. (2013). Jogo educativo na promoção da saúde de adolescentes: Revisão integrativa. Revista eletrônica de enfermagem, 15, 265-273. https://doi.org/10.5216/ree.v15i1.17814

Medeiros, R., Lima, R., Silva, D., \& Mercado, L. P. (2015). Jogos Digitais como Estratégia de Ensino-Aprendizagem no Ensino Superior: A construção e aplicação do game Renascença na disciplina de Literatura. Salvador: XI Seminário SJEEC, 126-134.

Perim, C. M., Giannella, T. R., \& Struchiner, M. (2014). Análise do uso de um Jogo para Educação em Saúde com Adolescentes. IV Encontro Nacional de Ensino de Ciências da Saúde e do Ambiente, Niterói, 1-12.

Rufino, T. C. (2014). O lúdico na sala de aula em séries iniciais do Ensino Fundamental. Specialization Dissertation, Guarabira: Paraíba State University.

Sangiorgio, J. P., Gabriel, M., Moreira, F. S., \& Tanaka, E. (2011). Geração Y: A motivação para construção do conhecimento. Abeno, 11, 14-18.

Santos, W. P., \& Lisboa, W. T. (2014). Características psicossociais e práticas de consumo dos "nativos digitais": Implicações, permanência e tendências na comunicação organizacional. Comunicação \& Mercado/UNIGRAN, 3, 98-110.

Savi, R., Wangenheim, C. G., Ulbricht, V., \& Vanzin, T. (2010). Proposta de um Modelo de Avaliação de Jogos Educacionais. Renote, 8, 1-12.

Silva, C. J., \& Rosa, D. L. (2010). Aplicação de atividades lúdicas no ensino superior como forma de fixação de conteúdos ministrados (pp. 1-42). Specialization Dissertation, Rio de Janeiro: Universidade Cândido Mendes.

Silva, I. K., \& Morais, M. J. (2011). Desenvolvimento de jogos educacionais no apoio do processo de ensino aprendizagem no ensino fundamental. Holos Environment, 5, 153-164. https://doi.org/10.15628/holos.2011.705

Takatalo, J., Hakkinen, J., Kaistinen, J., \& Nyman, G. (2010). Presence, Involvement, and Flow in Digital Games. In R. Bernhaupt (Ed.), Evaluating User Experience in Games: Concepts and Methods (pp. 23-46). Springer. https://doi.org/10.1007/978-1-84882-963-3_3

Toledo, P. B., Albuquerque, R. A., \& Magalhães, A. R. (2012). O Comportamento da Geração $Z$ e a influência nas atitudes dos professores. IX SEGeT Simpópio de Excelência em Gestão e Tecnologia. Cuiabá, 1-16. 
C. F. G. de Carvalho et al.

Yonekura, T., \& Soares, C. B. (2010). O jogo educativo como estratégia de sensibilização para coleta de dados com adolescentes. Revista Latino-Americana de Enfermagem, 18, 968-974. https://doi.org/10.1590/S0104-11692010000500018 


\section{Appendix}

\section{Instrument of evaluation of the perception of the participants as to the "immunization"}

Instructions: $1=$ disagree totally; $2=$ moderadmante discord; $3=$ indifferent; $4=\mathrm{i}$ agree moderately; $5=$ totally agree

\begin{tabular}{|c|c|c|c|c|c|c|}
\hline \multirow{2}{*}{ QT } & \multirow{2}{*}{ QUESTION } & \multicolumn{5}{|c|}{ LIKERT TYPE SCALE } \\
\hline & & 1 & 2 & 3 & 4 & 5 \\
\hline 1 & There was something interesting at the beginning of the game that caught my attention. & & & & & \\
\hline 2 & The design of the game interface is attractive. & & & & & \\
\hline 3 & It became clear to me how the content of the game is related to things I already knew. & & & & & \\
\hline 4 & I liked the game so much that I would like to learn more about the subject covered by it. & & & & & \\
\hline 5 & The content of the game is relevant to my interests & & & & & \\
\hline 6 & I could relate the content of the game to things I've seen, done, or thought. & & & & & \\
\hline 7 & The content of the game will be useful to me. & & & & & \\
\hline 8 & The game was harder to understand than I would like. & & & & & \\
\hline 9 & $\begin{array}{l}\text { The game had so much information that it was difficult } \\
\text { to identify and remember the important points. }\end{array}$ & & & & & \\
\hline 10 & The activities of the game were very difficult. & & & & & \\
\hline 11 & I could not understand a good portion of the game material. & & & & & \\
\hline 12 & I learned some things with the game that were surprising or unexpected. & & & & & \\
\hline 13 & I felt good about completing the game. & & & & & \\
\hline 14 & I did not realize the time passed while playing. & & & & & \\
\hline 15 & I struggled to get good results in the game. & & & & & \\
\hline 16 & There were times when I wanted to give up the game. & & & & & \\
\hline 17 & I felt stimulated to learn from the game. & & & & & \\
\hline 18 & I liked the game and did not feel anxious or bored. & & & & & \\
\hline 19 & The game kept me motivated to continue using it. & & & & & \\
\hline 20 & This game is adequately challenging for me, the tasks are not too easy or too difficult. & & & & & \\
\hline 21 & Collaboration in the game helps learning. & & & & & \\
\hline 22 & The game supports social interaction between players. & & & & & \\
\hline 23 & I would play this game again. & & & & & \\
\hline 24 & I was hoping for the game to end soon & & & & & \\
\hline 25 & $\begin{array}{l}\text { After the game I can remember more information related to the theme } \\
\text { presented in the game. }\end{array}$ & & & & & \\
\hline 26 & After the game I can better understand the themes presented in the game. & & & & & \\
\hline 27 & After the game I feel that I can better apply the themes related to the game. & & & & & \\
\hline
\end{tabular}

Source: Questions taken from Savi, Wangenheim, Ulbricht, Vanzin instrument, 2010.

Reference: Savi, R., Wangenheim, C. G. V., Ulbricht, V., \& Vanzin, T. (2010). Proposal for a Model of Evaluation of Educational Games, New Technologies in Education. UFRGS, 8 . 